\title{
Acetoanaerobium noterae gen. nov., sp. nov.: an Anaerobic Bacterium That Forms Acetate from $\mathrm{H}_{2}$ and $\mathrm{CO}_{2}$
}

\author{
ROBERT SLEAT,${ }^{1}$ ROBERT A. MAH, ${ }^{1 *}$ AND RALPH ROBINSON ${ }^{2}$ \\ Division of Environmental and Occupational Health Sciences, School of Public Health, University of California, Los \\ Angeles, California $90024^{1}$ and Department of Microbiology and Cell Science, University of Florida, \\ Gainesville, Florida $32611^{2}$
}

\begin{abstract}
An anaerobic bacterium which produced acetate from $\mathrm{H}_{2}$ and $\mathrm{CO}_{2}$ was isolated. The rod-shaped cells were not lysed by $\mathrm{KOH}$, did not hydrolyze L-alanine-4-nitroanilide, and stained gram negative. However, the cell wall did not resemble a gram-negative wall in structure; it was comprised of two layers. The cells were motile by means of three or four peritrichous flagella. Yeast extract was required for both chemoorganotrophic and chemolithotrophic growth; yeast extract, glucose, maltose, or $\mathrm{H}_{2}-\mathrm{CO}_{2}$ could serve as a substrate for growth. Strain NOT- ${ }^{\mathrm{T}}$ ( $\mathrm{T}=$ type strain) grew best at $37^{\circ} \mathrm{C}$ and $\mathrm{pH} 7.6$ to 7.8 . The deoxyribonucleic acid base composition was 36.8 mol\% guanine plus cytosine. Strain NOT-3 (= ATCC 35199) is named Acetoanaerobium noterae gen. nov., sp. nov. and is the type strain of this new species.
\end{abstract}

Acetate production by $\mathrm{H}_{2}$-dependent $\mathrm{CO}_{2}$ reduction was first demonstrated in enrichment cultures (9). Subsequently, Clostridium aceticum, which grows readily in the presence of $\mathrm{H}_{2}$ and $\mathrm{CO}_{2}$, was isolated by Wieringa (20). Acetate is the only product formed by this organism. The original culture of Wieringa was presumably lost for many years but was recently revived from an old endospore preparation (5). Isolates similar to $C$. aceticum have been described by other workers $(1,14)$. Anaerobic $\mathrm{H}_{2}$-oxidizing acetogenic bacteria can be found in a number of environments (6). Other species with this property have been described in the genera Acetobacterium (2, 4), Acetogenium (11), Eubacterium (18), and Clostridium (19), including thermophilic species $(11,19)$.

A sediment sample taken from an oil exploration drilling site was examined for the presence of methanogens. High dilutions of the sample showed $\mathrm{H}_{2}$ uptake and acetate production without methanogenesis. A bacterium which produced acetate from $\mathrm{H}_{2}$ and $\mathrm{CO}_{2}$ was isolated from these dilutions. This organism (strain NOT-3 $\left[=\right.$ ATCC $\left.35199^{\mathrm{T}}\right]$ ) ( $\mathrm{T}=$ type strain) is named Acetoanaerobium noterae gen. nov., sp. nov.

(A brief report of this work appeared previously [Sleat, Mah, and Robinson, Abstr. Annu. Meet. Am. Soc. Microbiol. 1983, I54, p. 148].)

\section{MATERIALS AND METHODS}

Bacterial strains. Strain NOT $-3^{\mathrm{T}}$ was isolated from sediment of the Notera 3 oil exploration drilling site in the Hula swamp area of Galilee, Israel. The sediment $\mathrm{pH}$ was 8.0. Polyethylene bottles were filled with sediment samples, shipped to the laboratory, and stored under $\mathrm{O}_{2}$-free $\mathrm{N}_{2}$ at $4^{\circ} \mathrm{C}$.

Culture medium. The culture medium used was prepared by using the techniques of Hungate (10). This medium contained (per liter) $0.4 \mathrm{~g}$ of $\mathrm{K}_{2} \mathrm{HPO}_{4} \cdot 3 \mathrm{H}_{2} \mathrm{O}, 1.0 \mathrm{~g}$ of $\mathrm{NH}_{4} \mathrm{Cl}, 0.45 \mathrm{~g}$ of $\mathrm{NaCl}, 2.0 \mathrm{~g}$ of yeast extract (Difco Laboratories, Detroit, Mich.), $0.15 \mathrm{~g}$ of L-cysteine hydrochloride, and $0.001 \mathrm{~g}$ of resazurin; $10 \mathrm{ml}$ of a trace metal solution (8) and $10 \mathrm{ml}$ of vitamin solution (5) were added per liter. The medium was adjusted to $\mathrm{pH} 7.0$ with $4 \mathrm{~N} \mathrm{NaOH}$, dispensed under a gas phase of either $\mathrm{H}_{2}-\mathrm{CO}_{2}$ (4:1) or $\mathrm{N}_{2}-\mathrm{CO}_{2}$ (4:1), and autoclaved. Before inoculation the $\mathrm{pH}$

\footnotetext{
* Corresponding author.
}

was adjusted (usually to 8.0 ) with a sterile $\mathrm{Na}_{2} \mathrm{CO}_{3}$ solution, and $\mathrm{Na}_{2} \mathrm{~S} \cdot 9 \mathrm{H}_{2} \mathrm{O}$ (final concentration, $0.15 \mathrm{~g} /$ liter) was added from a sterile stock solution. Solid media also contained $1.5 \%$ purified agar (Difco). For substrate utilization experiments the yeast extract concentration was reduced to 0.5 $\mathrm{g} /$ liter, and substrate was added from a sterile anaerobic stock solution to give a final concentration of $10 \mathrm{mM}$.

Most-probable-number determinations. The medium used for most-probable-number determinations contained (per liter) $2.0 \mathrm{~g}$ of Trypticase peptone (BBL Microbiology Systems, Cockeysville, Md.), $2.5 \mathrm{~g}$ of sodium acetate, and $2.5 \mathrm{~g}$ of sodium formate. Sediment ( $1 \mathrm{~g}$, wet weight) was added to $5 \mathrm{ml}$ of medium, the container was aseptically stoppered, and the preparation was blended vigorously in a Vortex mixer. The resulting sediment slurry was decimally diluted; $0.2 \mathrm{ml}$ of each dilution was inoculated into each of five tubes containing $5 \mathrm{ml}$ of medium with an $\mathrm{H}_{2}-\mathrm{CO}_{2}$ gas phase. The tubes were incubated at $35^{\circ} \mathrm{C}$ with vigorous shaking. $\mathrm{H}_{2}$ utilization and $\mathrm{CH}_{4}$ production were determined by gas analysis (3). The most probable numbers of $\mathrm{H}_{2}$-oxidizing bacteria were determined from previously published statistical tables (13).

Isolation of DNA and analysis of base composition. Deoxyribonucleic acid (DNA) was extracted with chloroformisoamyl alcohol and purified (16). The buoyant density of the purified DNA was determined by ultracentrifugation is a CsCl gradient (15). DNAs from Escherichia coli strain B and Clostridium perfringens were used as references. The DNA guanine-plus-cytosine content was calculated from its buoyant density (17).

Microscopy. A Zeiss Universal Research microscope (Carl Zeiss, Oberkochen, West Germany) equipped with phase optics was used for photomicroscopy. For thin-section electron microscopy, broth-grown cells were fixed for $20 \mathrm{~min}$ in $0.1 \mathrm{M}$ cacodylate buffer ( $\mathrm{pH} 7.2$ ) containing $2 \%$ formaldehyde and $2.5 \%$ glutaraldehyde. After the cells were washed with buffer, they were fixed in buffered $1 \% \mathrm{OsO}_{4}$ for $1 \mathrm{~h}$. The cells were then enrobed in agar, dehydrated, and embedded in Spurr plastic. Thin sections were stained with uranyl and lead salts. Sections were examined with a Jeol model 100CX electron microscope. For scanning electron microscopy, a colony growing on agar was fixed for 20 min with $2.5 \%$ glutaraldehyde in cacodylate buffer. It was then dehydrated in alcohol, critical-point dried, and gold coated. The colony 


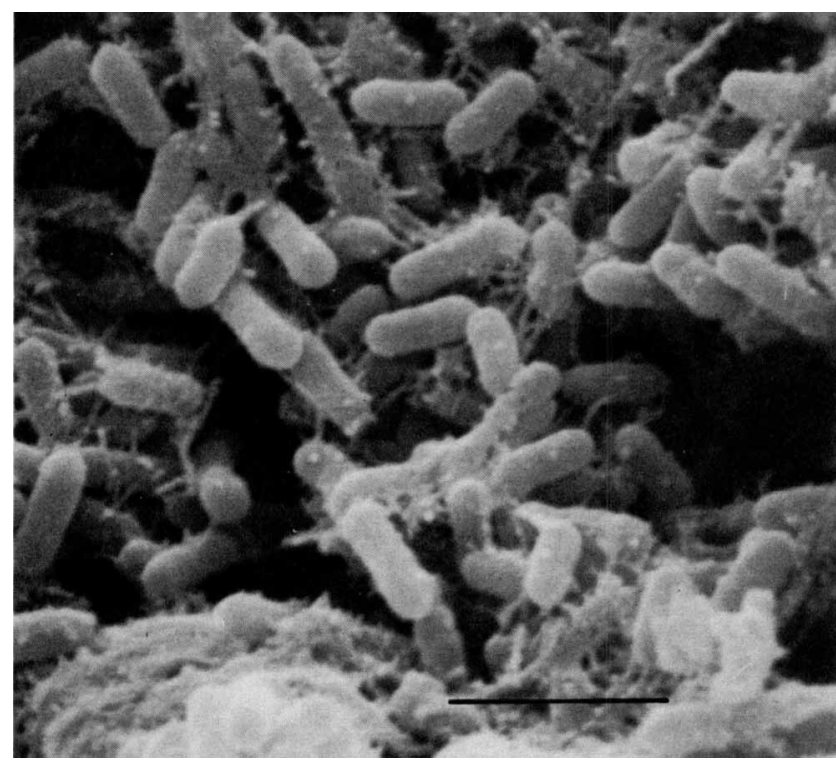

FIG. 1. Scanning electron photomicrograph of cells of Acetoanaerobium noterae from a roll tube colony. $\mathrm{Bar}=1 \mu \mathrm{m}$.

was observed with a Hitachi model S-450 scanning electron microscope.

Analytical techniques. Gram stain reactions, lysis by $\mathrm{KOH}$, and hydrolysis of L-alanine-4-nitroanilide were determined by the methods of Carlone et al. (7). Growth of strain NOT $-3^{\mathrm{T}}$ in broth was measured by absorbance at $540 \mathrm{~nm}$.
Gases were analyzed by gas chromatography, and volatile fatty acids were measured by gas chromatography after acidification with $\mathrm{H}_{3} \mathrm{PO}_{4}$ and centrifugation (3).

\section{RESULTS AND DISCUSSION}

Numbers of $\mathbf{H}_{2}$-oxidizing acetogens. The most-probablenumber analysis of the drilling site sample yielded $1.75 \times 10^{5}$ $\mathrm{H}_{2}$-oxidizing acetogens per $\mathrm{g}$ (wet weight). No methane was detected in any of the tubes. A microscopic examination of the cultures positive for $\mathrm{H}_{2}$ utilization revealed bacteria with morphology similar to that of the isolate, strain NOT $-3^{\mathrm{T}}$; using tubes from the highest dilution as inoculum, we isolated several $\mathrm{H}_{2}$-oxidizing acetogens morphologically similar to strain NOT $-3^{\mathrm{T}}$.

Isolation of strain NOT-3 $3^{\mathrm{T}}$. Non-methanogenic $\mathrm{H}_{2-}$ oxidizing organisms were enriched by inoculating $0.5 \mathrm{~g}$ of sediment into $5 \mathrm{ml}$ of medium with $\mathrm{H}_{2}-\mathrm{CO}_{2}$ gas; this enrichment culture was incubated at $35^{\circ} \mathrm{C}$ for 3 days. $\mathrm{No} \mathrm{CH}_{4}$ was detected, but $\mathrm{H}_{2}$ uptake occurred. Decimal dilutions of the enrichment were made, and roll tubes were inoculated at each dilution. After incubation for $24 \mathrm{~h}$, punctiform colonies appeared at the high dilution. Several of these colonies were picked, diluted, and inoculated into roll tube media for purification. One typical rod-shaped isolate, strain NOT-3 ${ }^{\mathrm{T}}$ (Fig. 1), was chosen for further study; it was picked, transferred to liquid medium, and subsequently maintained by $5 \%$ transfer every 14 days.

The cells stained gram negative, did not hydrolyze Lalanine-4-nitroanilide, and were not lysed by $\mathrm{KOH}$. However, the double-layered cell wall did not resemble a typical

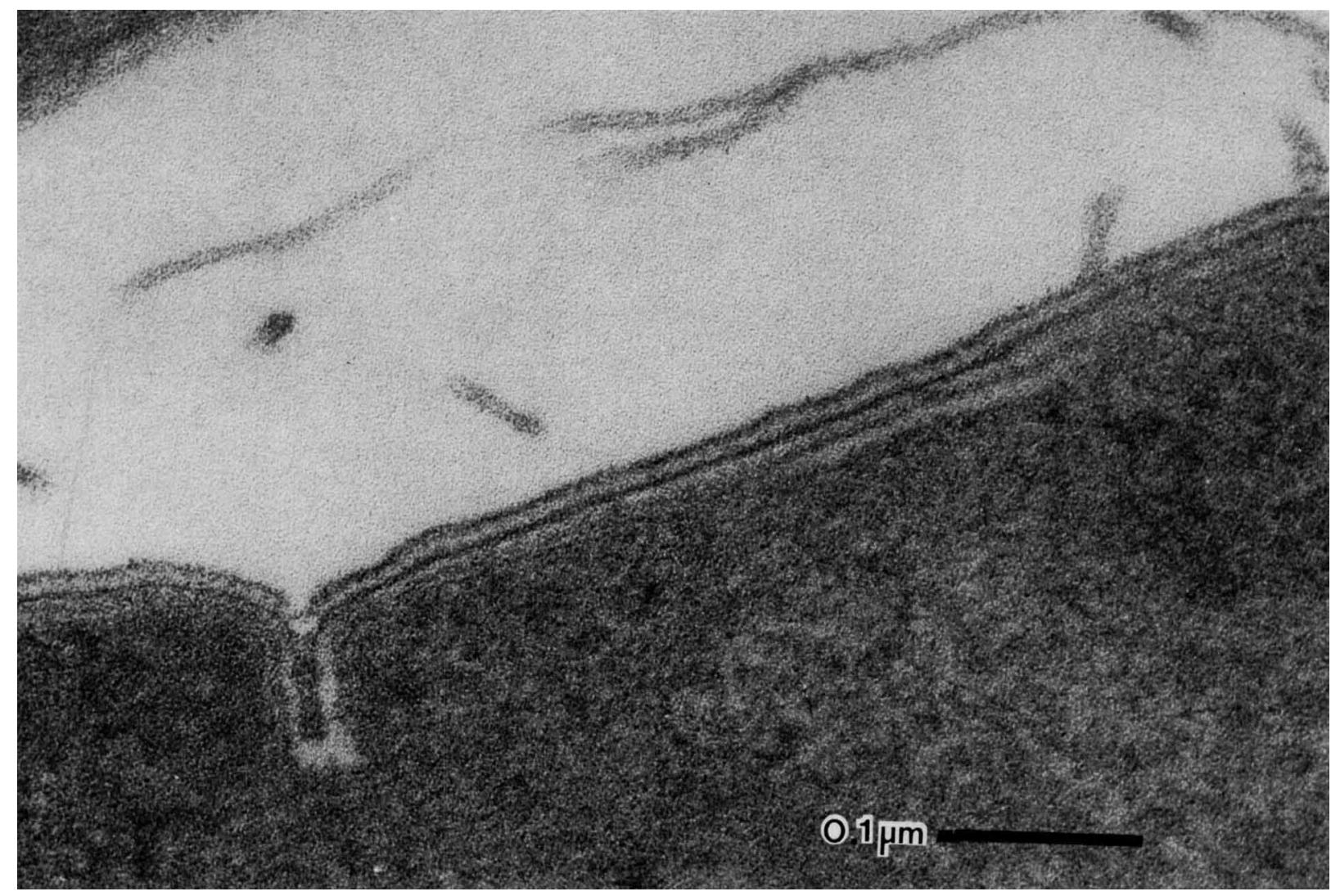

FIG. 2. Thin section of Acetoanaerobium noterae showing two-layer cell wall. 


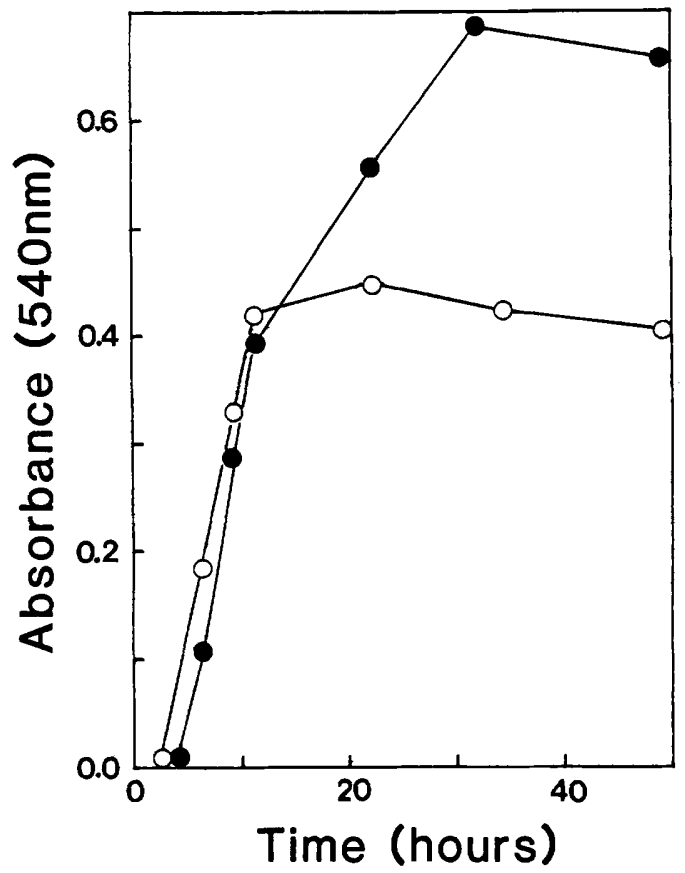

FIG. 3. Growth of Acetoanaerobium noterae on yeast extract with an $\mathrm{N}_{2}-\mathrm{CO}_{2}(\bullet)$ or $\mathrm{H}_{2}-\mathrm{CO}_{2}(\mathrm{O})$ gas phase.

gram-negative cell wall in structure (Fig. 2). In liquid culture, cells often occurred in pairs and, during the stationary phase, in long chains. Endospores were not found by either phase-contrast or electron microscopy. Spore staining of old cultures by the malachite green method also failed to reveal the presence of endospores. Furthermore, no growth occurred after cultures were exposed to $70^{\circ} \mathrm{C}$ for 15 $\min$.

Higher cell yields were obtained on yeast extract medium when $\mathrm{H}_{2}-\mathrm{CO}_{2}$ replaced $\mathrm{N}_{2}-\mathrm{CO}_{2}$ as the gas phase. In fact, growth was biphasic (Fig. 3) under these conditions. The initial rapid growth phase was similar to growth in the absence of $\mathrm{H}_{2}$. There followed a period of growth at a greatly reduced rate, which occurred only in the presence of $\mathrm{H}_{2} . \mathrm{H}_{2}$ uptake occurred throughout both phases of the growth cycle but was greatly increased during the second phase of growth $\left(\mathrm{H}_{2}\right.$-dependent growth). Some cultures utilized $\mathrm{H}_{2}$ for more than 100 days after the onset of the stationary growth phase. Higher initial concentrations of yeast extract increased the rate of $\mathrm{H}_{2}$-dependent growth, and higher cell yields were obtained (Fig. 4). $\mathrm{H}_{2}$ uptake occurred over a much longer time at the lower initial yeast extract concentrations. However, in the complete absence of yeast extract, $\mathrm{H}_{2}$ was not utilized.

In the presence of $\mathrm{H}_{2}-\mathrm{CO}_{2}$, acetate production was stoichiometrically and temporally related to $\mathrm{H}_{2}$ uptake during the $\mathrm{H}_{2}$-utilizing phase of growth (Table 1 and Fig. 5). The theoretical stoichiometry yielded $1 \mathrm{~mol}$ of acetate per $4 \mathrm{~mol}$ of $\mathrm{H}_{2}$ used; we found approximately $4.3 \mathrm{~mol}$ of $\mathrm{H}_{2}$ consumed per mol of acetate formed. In addition to an increase in acetate production, a much smaller increase in butyrate production (Table 1 ) also occurred during the $\mathrm{H}_{2}$-dependent growth phase. When either glucose or maltose served as the substrate, acetate was the only fermentation product. However, when yeast extract served as the substrate, propionate, butyrate, isobutyrate, and isovalerate were also formed (Table 1).

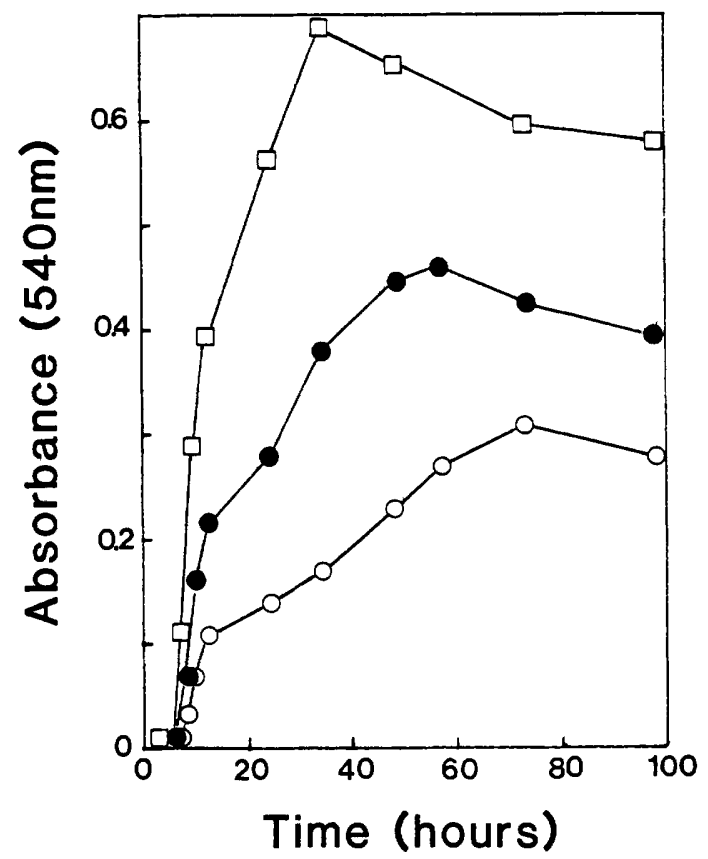

FIG. 4. Growth of Acetoanaerobium noterae with $\mathrm{H}_{2}-\mathrm{CO}_{2}$ and the following concentrations of yeast extract: $0.05 \%(\mathrm{wt} / \mathrm{vol})(\mathrm{O})$, $0.1 \%(\mathrm{wt} / \mathrm{vol})(\bullet)$, and $0.2 \%(\mathrm{wt} / \mathrm{vol})(\square)$.

Taxonomy. Strain NOT $-3^{\mathrm{T}}$ differed significantly from previously described bacteria which produce acetate from $\mathrm{H}_{2}$ and $\mathrm{CO}_{2}$ (Table 2). The acetogenic organisms selected for comparison in Table 2 have guanine-plus-cytosine contents ranging from 33 to $43 \mathrm{~mol} \%$. The value for strain NOT $-3^{\mathrm{T}}$ fell within this range. Data for Eubacterium limosum (18) and Clostridium thermoautotrophicum (19) were omitted from Table 2 because the guanine-plus-cytosine contents of these organisms ( 49 and 53 to $55 \mathrm{~mol} \%$, respectively) fall outside this range, and thus strain NOT $-3^{\mathrm{T}}$ was not closely related to these species.

Strain NOT $-3^{\mathrm{T}}$ is not a member of the genus Clostridium because it did not form endospores. It is not a member of the genus Acetobacterium because it stained gram negative. It differed from Acetogenium kivui in cell wall structure and temperature optimum, as well as several other characteristics $(11,12)$; these differences warrant recognition of strain NOT $-3^{\mathrm{r}}$ as a new species representing a new genus. Thus, we name strain NOT-3 ${ }^{\mathrm{T}}$ Acetoanaerobium noterae gen. nov., sp. nov.

We propose that the genus Acetoanaerobium be placed in the family Bacteroidaceae with the generic description given below.

TABLE 1. Volatile fatty acids produced by Acetoanaerobium noterae during growth on yeast extract ${ }^{a}$

\begin{tabular}{ccccccc}
\hline Gas phase & $\begin{array}{c}\mathrm{H}_{2} \text { up- } \\
\text { take } \\
(\mu \mathrm{mol})\end{array}$ & \multicolumn{4}{c}{ Volatile fatty acids formed $(\mu \mathrm{mol})^{b}$} \\
\cline { 5 - 8 } & Acetate & $\begin{array}{c}\text { Propio- } \\
\text { nate }\end{array}$ & $\begin{array}{c}\text { Isobu- } \\
\text { tyrate }\end{array}$ & Butyrate & $\begin{array}{c}\text { Iso- } \\
\text { valerate }\end{array}$ \\
\hline $80 \% \mathrm{~N}_{2}-20 \% \mathrm{CO}_{2}$ & & 154 & 21 & 10 & 15 & 17 \\
$80 \% \mathrm{H}_{2}-20 \% \mathrm{CO}_{2}$ & 2,193 & 643 & 23 & 9 & 23 & 16 \\
\hline
\end{tabular}

a The experimental vials contained $\mathrm{N} 1$ medium supplemented with $0.2 \%$ yeast extract and were inoculated with $0.1 \mathrm{ml}$ of a culture grown on $0.2 \%$ yeast extract under $\mathrm{H}_{2}-\mathrm{CO}_{2}$. The vials were incubated at $37^{\circ} \mathrm{C}$ with shaking for 376 h.

${ }^{b}$ Values are averages of three experimental vials. 
Acetoanaerobium gen. nov. Acetoanaerobium (A.ce.to.an.ae. ro bi.um. L. n. acetum vinegar; Gr. pref. an not; Gr. n. aer air; Gr. n. bios life; M. L. neut. n. Acetoanaerobium vinegar anaerobe) cells are nonsporeforming rods. Cells stain gram negative but have an atypical gram-negative wall structure.

Chemoorganotrophs. Ferment carbohydrates, producing acetate and sometimes other volatile acids. Ferment yeast extract, producing acetate and several volatile acids. At slower growth rates produce acetate from $\mathrm{H}_{2}$ and $\mathrm{CO}_{2}$; may require yeast extract for growth.

Obligately anaerobic.

The type species is Acetoanaerobium noterae.
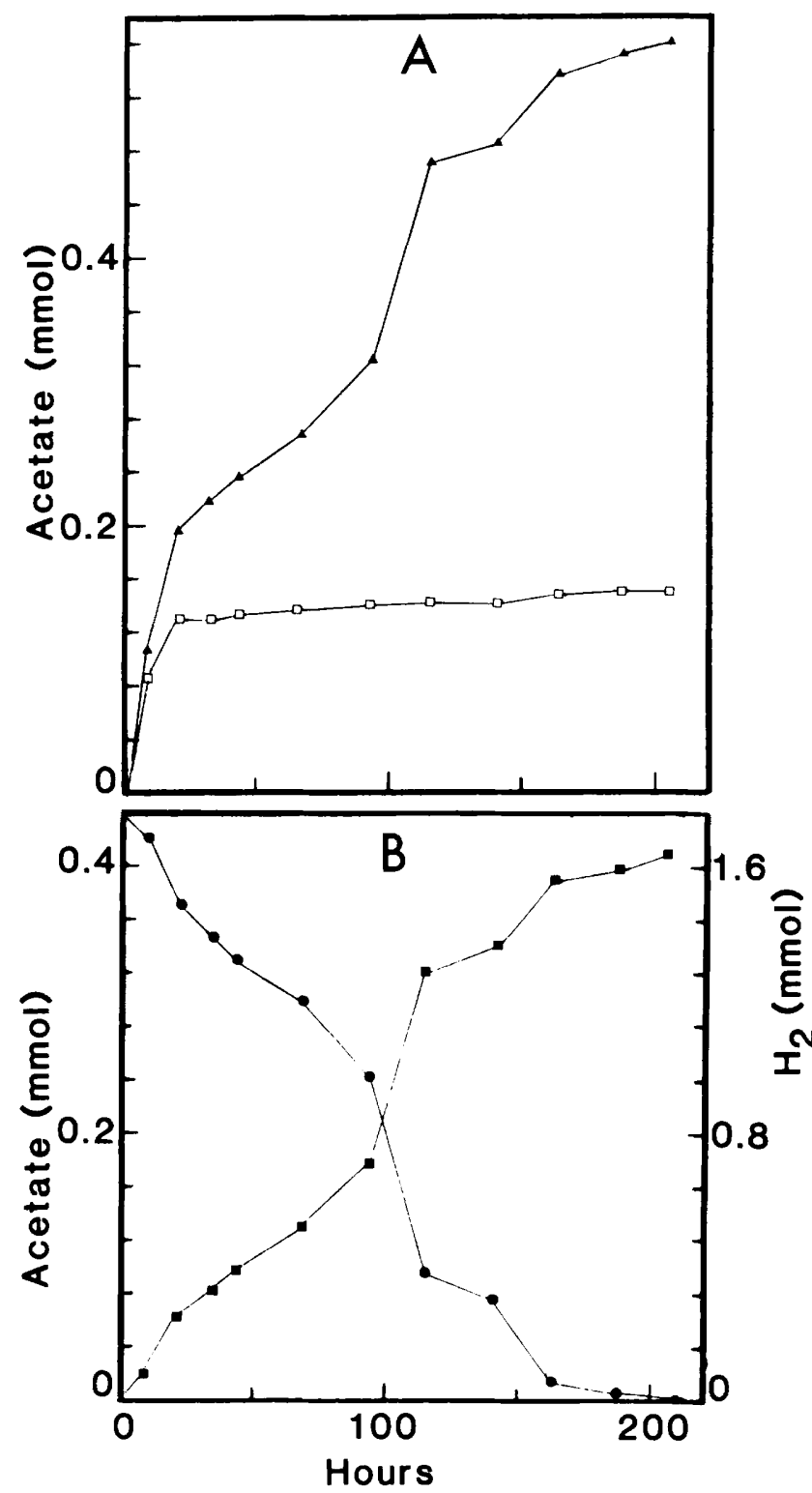

FIG. 5. $\mathrm{H}_{2}$-dependent acetate formation from $\mathrm{H}_{2}-\mathrm{CO}_{2}$ in the presence of $0.2 \%(\mathrm{wt} / \mathrm{vol}$ ) yeast extract. (A) Acetate formation in the presence of $\mathrm{N}_{2}-\mathrm{CO}_{2}$ and $0.2 \%(\mathrm{wt} / \mathrm{vol})$ yeast extract $(\square)$ or $\mathrm{H}_{2}-\mathrm{CO}_{2}$ and $0.2 \%$ yeast extract $(\mathbf{\Delta})$. (B) Net acetate formation (total acetate production minus acetate production from yeast extract alone) ( verus $\mathrm{H}_{2}$ utilization (๑).

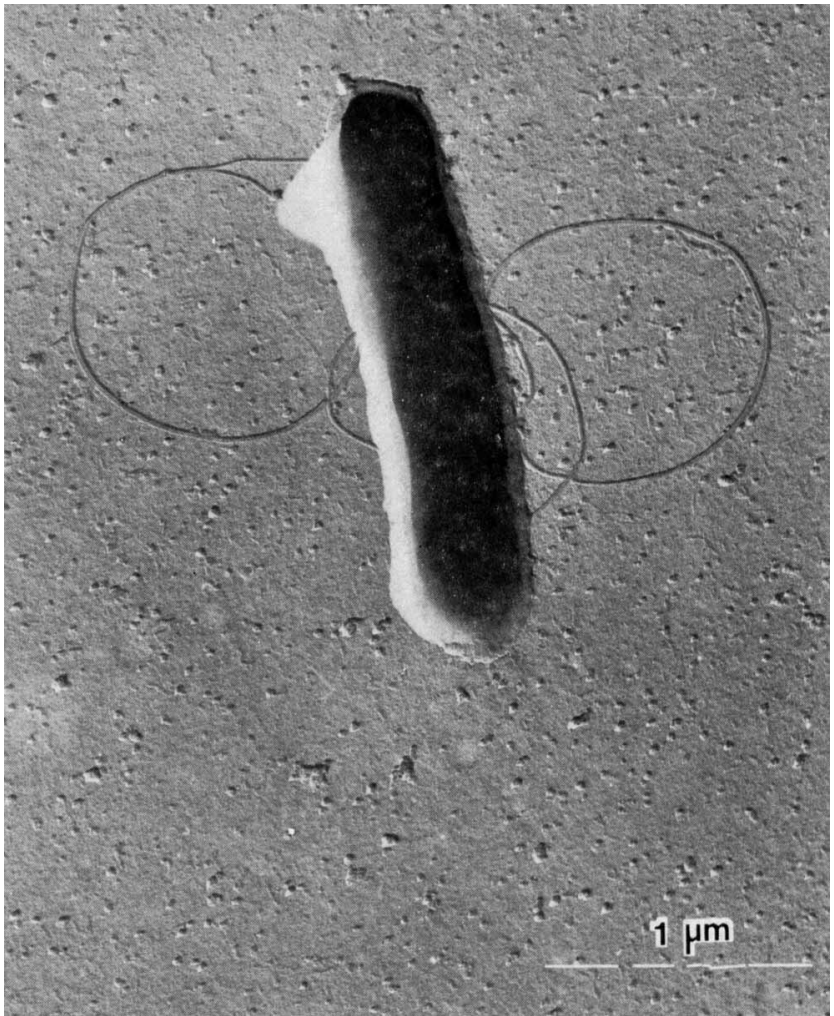

FIG. 6. Platinum shadow replica of Acetoanaerobium noterae showing three or four peritrichous flagella.

Acetoanaerobium noterae sp. nov. Acetoanaerobium noterae (no'ter.ae. L. adj. notera' pertaining to Notera; named for its source, the Notera oil exploration site in Israel) cell are straight rods that are $0.8 \mu \mathrm{m}$ wide and 1 to $5 \mu \mathrm{m}$ long. Motile, with three or four peritrichous flagella (Fig. 6). Cells stain gram negative; the cell wall is atypical and, as determined by transmission electron microscopy, is composed of two distinct layers, a darker inner layer and lighter outer layer. Colonies are rhizoid, opaque, and granular (Fig. 7). Young colonies are white, but older colonies are brownish and up to $2 \mathrm{~cm}$ in diameter after 1 month of incubation.

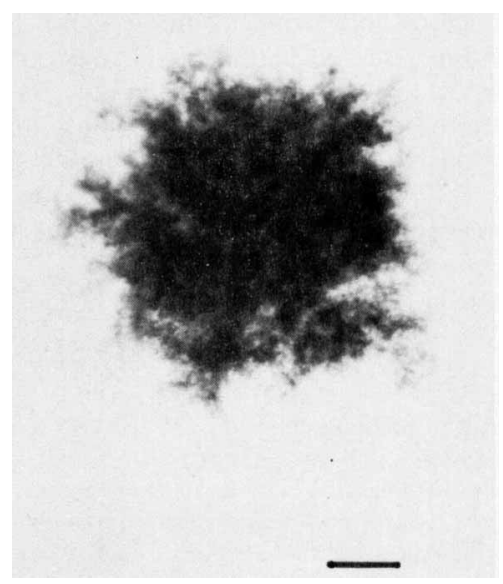

FIG. 7. Photomicrograph of an Acetoanacrobium noterae colony. Bar $=1 \mathrm{~mm}$. 
TABLE 2. Comparison of stain NOT-3T with other $\mathrm{H}_{2}$-oxidizing acetogenic bacteria

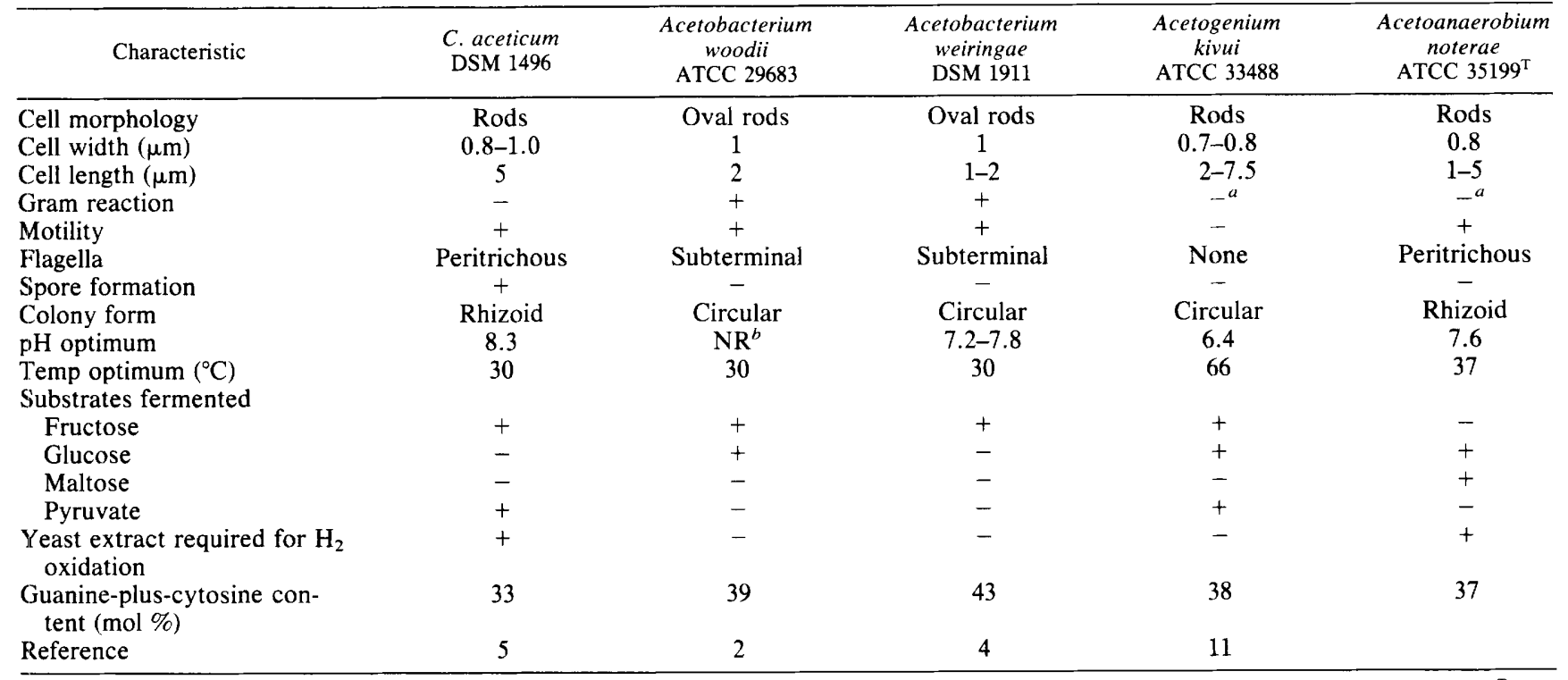

${ }^{a}$ Transmission electron micrographs show gram-positive cell wall structure of Acetogenium kivui but an atypical double-layered wall of strain NOT-3 ${ }^{\mathrm{T}}$

${ }^{b}$ NR, Not reported.

Yeast extract, maltose, and glucose are used for heterotrophic growth. Compounds not supporting growth include arabinose, rhamnose, ribose, xylose, fructose, galactose, cellobiose, lactose, mannose, sucrose, melezitose, trehalose, erythritol, adonitol, arabitol, dulcitol, inositol, mannitol, sorbitol, formate, acetate, pyruvate, lactate, malate, fumarate, succinate, citrate, glutamate, methylamine, trimethylamine, and methanol.

Yeast extract is required for growth and $\mathrm{H}_{2}$ utilization. Growth on yeast extract and $\mathrm{H}_{2}-\mathrm{CO}_{2}$ is biphasic, with an initial rapid growth phase independent of the presence of $\mathrm{H}_{2}$. This is followed by $\mathrm{H}_{2}$-dependent acetate production during the second slower growth phase.

Cells produce acetate, propionate, isobutyrate, butyrate, and isovalerate (and little or no $\mathrm{H}_{2}$ ) during growth on yeast extract alone. When either glucose or maltose serves as a substrate, acetate is the only fermentation product.

Obligately anaerobic. Growth is most rapid at $37^{\circ} \mathrm{C}$ and $\mathrm{pH} 7.6$ ( $\mathrm{pH}$ range, 6.6 to 8.4). Minimum doubling times are $2.8 \mathrm{~h}$ for heterotrophic growth and $27 \mathrm{~h}$ for $\mathrm{H}_{2}$-dependent growth. Vitamins are not required. Growth is inhibited by erythromycin, chloramphenicol, penicillin, cephalosporin, and cycloserine at concentrations of $100 \mathrm{ng} / \mathrm{liter}$.

The DNA base composition is $37 \mathrm{~mol} \%$ guanine plus cytosine.

Isolated from sediment near the Notera oil drilling site in the Hula swamp area of Galilee, Israel.

The type strain is strain NOT-3 (= ATCC 35199).

\section{ACKNOWLEDGMENTS}

Sediment samples were kindly provided by A. Nissenbaum, Weizmann Institute of Science, Rehovot, Israel, and I. R. Kaplan, Department of Earth and Space Sciences, University of California at Los Angeles, Los Angeles. We thank T. J. Ferguson, H. Negoro, B. Ollivier, and I. M. Mathrani for many helpful discussions and D. R. Boone and D. A. Kuhn for reviewing the final version of the manuscript.

This work was supported by grants 5080-323-0423 and IFAS-GRIFIA-MCS 2171 from the Gas Research Institute and by research contract DE-AT03-80ER10684 from the Department of Energy.

\section{LITERATURE CITED}

1. Adamse, A. D. 1980 . New isolation of Clostridium aceticum (Wieringa). Antonie van Leeuwenhoek J. Microbiol. Serol. 46:523-531.

2. Balch, W. E., S. Schoberth, R. S. Tanner, and R. S. Wolfe. 1977. Acetobacterium, a new genus of hydrogen-oxidizing, carbon dioxide-reducing, anaerobic bacteria. Int. J. Syst. Bacteriol. 27:355-361.

3. Baresi, L., R. A. Mah, D. M. Ward, and I. R. Kaplan. 1978. Methanogenesis from acetate: enrichment studies. Appl. Environ. Microbiol. 36:186-197.

4. Braun, M., and G. Gottschalk. 1982. Acetobacterium wieringae sp. nov., a new species producing acetic acid from molecular hydrogen and carbon dioxide. Zentralbl. Bakteriol. Parasitenkd. Infektionskr. Hyg. Abt. 1 Orig. Reihe C 3:368-376.

5. Braun, M., F. Mayer, and G. Gottschalk. 1981. Clostridium aceticum (Wieringa), a microorganism producing acetic acid from molecular hydrogen and carbon dioxide. Arch. Microbiol. 128:288-293.

6. Braun, M., S. Schoberth, and G. Gottschalk. 1979. Enumeration of bacteria forming acetate from $\mathrm{H}_{2}$ and $\mathrm{CO}_{2}$ in anaerobic habitats. Arch. Microbiol. 120:201-204.

7. Carlone, G. M., M. J. Valadez, and M. J. Pickett. 1982. Methods for distinguishing gram-positive from gram-negative bacteria. J. Clin. Microbiol. 16:1157-1159.

8. Ferguson, T. J., and R. A. Mah. 1983. Isolation and characterization of an $\mathrm{H}_{2}$-oxidizing thermophilic methanogen. Appl. Environ. Microbiol. 45:265-274.

9. Fischer, F., R. Lieske, and K. Winzer. 1932. Biologische Gasreaktionen. II. Mitteilung: uber die Bildung von Essigsäure bei der biologischen Umsetzung von Kohlenoxyd und Kohlensäure mit Wasserstoff zu Methan. Biochem. Z. 245:2-12.

10. Hungate, R. E. 1969. A roll tube method for cultivation of strict anaerobes, p. 117-132. In R. Norris and D. W. Ribbons (ed.), Methods in microbiology, vol. 3B. Academic Press, Inc., New York.

11. Leigh, J. A., F. Mayer, and R. S. Wolfe. 1981. Acetogenium kivui, a new thermophilic hydrogen-oxidizing, acetogenic bacterium. Arch. Microbiol. 129:275-280.

12. Leigh, J. A., and R. S. Wolfe. 1983. Acetogenium kivui gen. nov., sp. nov., a thermophilic acetogenic bacterium. Int. J. 
Syst. Bacteriol. 33:886

13. Meynell, G. G., and E. Meynell. 1970. Theory and practice in experimental bacteriology. University Press, Cambridge.

14. Ohwaki, K., and R. E. Hungate. 1977. Hydroger utilization by clostridia in sewage sludge. Appl. Environ. Microbiol. 33:1270-1274.

15. Preston, J. F., and D. R. Boone. 1973. Analytical determination of the buoyant density of DNA in acrylamide gels after preparative $\mathrm{CsCl}$ gradient centrifugation. FEBS Lett. 37: 321-324.

16. Price, C. W., G. B. Fuson, and H. J. Phaff. 1978. Genome comparison in yeast systematics: delimitation of species within the genera Schwanniomyces, Saccharomyces, Debaryomyces, and Pichia. Microbiol. Rev. 42:161-193.
17. Schildkraut, C. L., J. Marmur, and P. Doty. 1962. Determination of the base composition of deoxyribonucleic acid from its buoyant density in CsCl. J. Mol. Biol. 4:430-443.

18. Sharak-Genthner, B. R., C. L. Davis, and M. P. Bryant. 1981 Features of rumen and sewage sludge strains of Eubacterium limosum, a methanol- and $\mathrm{H}_{2}-\mathrm{CO}_{2}$-utilizing species. Appl. Environ. Microbiol. 42:12-19.

19. Wiegel, J., M. Braun, and G. Gottschalk. 1981. Clostridium thermoautotrophicum species novum, a thermophile producing acetate from molecular hydrogen and carbon dioxide. Curr. Microbiol. 5:255-260.

20. Wieringa, K. T. 1940. The formation of acetic acid from carbon dioxide and hydrogen by anaerobic spore-forming bacteria. Antonie van Leeuwenhoek J. Microbiol. Serol. 6:251-262. 